Vol. 3, No. 1, 2016

UDC 330.11:338.54

H. M. Zakharchyn

Doctor of Economics , Professor,

N. P. Lyubomudrova

$\mathrm{PhD}$ of Economic Sciences,

I. B. Sobol,

Postgraduate student,

Lviv Polytechnic National University

\title{
MOTIVATION AND EVALUATION OF PERSONNEL IN MODERN CHALLENGING ENVIRONMENT
}

\begin{abstract}
Relationship between motivation and evaluation of the personnel in the enterprise management system as a purposeful influence on employees' performance is substantiated; the new tasks set before employees in modern challenging conditions are outlined. There are defined today's new challenges that are becoming a reality and are determining the new tasks set for national management. The basic essential components of personnel motivation and evaluation are presented; the content analysis of the personnel assessment tasks depending on manifestation of specific trends in society is made. Relevant principles of motivation and evaluation of personnel are indicated, the need for the formation of innovative mechanism for managing the personnel efficiency and work is emphasized. The mechanism is supposed to combine motivation and evaluation contexts and harmonize relations between employers, managers and employees.

Key words: motivation, personnel evaluation, motivators, motivational policy, personnel management.
\end{abstract}

\section{Formulation of the problem}

Today we are witnessing the emergence of new trends being of qualitatively different nature which are the laws of another dimension and which require new scientific and applied approaches to personnel management. In this context managers are challenged not only by the rational use of human resources but also by effective capitalization of the personnel's competences, skills and experience into the company's assets. Among all the aspects of the personnel management system employees' motivation and evaluation are most sensitive to changes. However, practices of personnel motivation and evaluation being intrinsic for foreign companies cannot always be adequately adopted by domestic enterprises. Besides, there is no systematic approach to the evaluation and motivation as a harmonious mechanism for managing both labor and enterprise. Managers do not bother looking for innovative tools of personnel motivation and evaluation, which exacerbates the problems associated with effective human capital management at domestic enterprises.

Analysis of recent research and publications

Personnel motivation and evaluation play a prominent role in the management of personnel, so this topic is covered in quite a lot of scientific papers by both domestic and foreign researchers. Scientists are exploring this topic in different directions, approaches, focusing on various aspects. Theoretical aspects of motivation, motivational techniques, value orientations of people, the basics of motivation are covered in publications of Ukrainian scientists [1, 5, 7, 8, 13]. Motivation and its relationship with organizational culture are dealt with in the author's monograph [2] and the article by O. V. Kharchyshyn [12]. The issues of evaluating personnel are explored by scientists who describe methods of personnel evaluation, current approaches to evaluating personnel, constituents of personnel evaluation $[3,5,9,14]$. The issues are dealt with either in the light of the company's efficiency [11, 15] or in the system of motivation itself [10]. Systematic scientific work by A. M. Kolot is also noteworthy [4]. The author integrally combines personnel motivation, promotion and evaluation into a single management mechanism. Undoubtedly estimating positively and appreciating the contribution of scientists to the development of these important theoretical and applied problems, we note that some aspects require further research. In particular, it is advisable that at present scientific 
ideas be looked at in terms of new trends, new challenges that will inevitably determine not only the theoretical and methodological approaches to economic processes and phenomena but will also change the instrumental component in the practical implementation of theoretical considerations. So a comprehensive statement of the scientific problem of finding an effective mechanism for improving the management of personnel is required, and in that approach staff motivation and evaluation should be an integral part and one whole.

The purpose of the article is to highlight the relationship of motivation and evaluation of personnel and to define new tasks in modern challenging conditions.

\section{Presentation of the main material}

Today it is necessary to track the current challenges in society, their influence on the structure of personal incentive systems to be able to form timely measures aimed at increasing motivation policies and methods of personnel evaluation.

The main modern challenges are:

- construction of civil society and the desire for greater freedom and responsibility;

- socialization and humanization of labor as a result of spreading socio-humanistic trends in management;

- promotion of cultural component in management that creates new value orientation of people, it being the basis of motivation;

- informatization of society and formation of virtual economy;

- transition processes occurring in our society that require not just adaptation to change but continuous human development, which should form the basis of motivational policies at enterprises;

- quality as a new essence in the evolutionary development of society, with its new content and meaning, requiring innovative approaches to instrumental component of personnel motivation and evaluation;

- time dimension as a factor of accelerating all processes and radical changes in technology, organization of work, which also stimulate development of other evaluation technologies and motivational tools.

These challenges have become reality and, accordingly, set new challenges for national management. Managers at various levels begin to practice new technologies of personnel management, seek new forms of personnel motivation and evaluation, and check their effectiveness and adequacy.

Relationship between personnel motivation and evaluation is clear as far as these are not only interrelated management functions, but also meaningful impacts on the activities of every person in the organization reflecting causal relationships. Usually motivation is considered to be a result of evaluating employee's performance. This relationship can also be reversed. In the system of motivation among other elements and features there is the evaluation function that allows comparing performance and reward, thus identifying the power of the motivational tool. In evaluating personnel three functions are also performed - administrative, informational and motivational. Thus, on the basis of evaluation there are taken important management decisions related to the system of motivation. Motivational objective of personnel evaluation is to choose adequate methods of motivation. At the same time, the motivational component of personnel evaluation allows to identify the timely feedback between managers and subordinates in terms of the results of their work. Personnel evaluation should not have a punitive character, making people psychologically tense. It should encourage and motivate development and improvement of their professional abilities. In this context, motivation is expected to be fundamental in the system of evaluation. Since these functions are interrelated and dependent the aim of top management should be to synthesize motivation and evaluation to obtain synergy effect. The relationship of the main components of motivation and evaluation is presented in Table 1.

Analyzing the main components of personnel motivation and evaluation, we note that in the process of motivation a personal incentive is important as a fundamental component while for evaluation the fundamental element is a set of parameters by which an employee's performance and effectiveness in the organization are judged. In this context, enterprise managers should pay attention to the use of special motives, which would provide opportunities to increase efficiency, responsibility and satisfaction from work, i.e. motivators. A motivator "is the most optimized motive, which provides a relatively stable expression of the appropriate response to stimulus" [8, p. 504]. Based on the fundamental component there is formed an incentive to action, the internal one for motivating an employee and the external one for evaluating employee's performance, and there taken 
actions based on the results, such as promotion, compensation or taking an appropriate management decision based on evaluation. Parametric-essential component can also be interpreted in different ways. Motivating personnel is more related to the aspects of quality, it especially concerns creative work where the material component may give way to the immaterial one, where the emotional and status factor as well as recognition weigh more than even wages. For the evaluation it is important to operate quantitative indicators which are necessary for determining the employee's labor cost and then, as a complementary element, for stimulating the employee.

\begin{tabular}{|c|c|c|}
\hline $\begin{array}{c}\text { Basic essential } \\
\text { components }\end{array}$ & Motivation & Evaluation \\
\hline $\begin{array}{c}\text { Fundamental } \\
\text { element }\end{array}$ & Motive & $\begin{array}{l}\text { A set of evaluation } \\
\text { parameters }\end{array}$ \\
\hline Incentive & Internal & External \\
\hline Goal & $\begin{array}{l}\text { Improving the } \\
\text { efficiency of } \\
\text { personnel and } \\
\text { enterprise } \\
\end{array}$ & $\begin{array}{l}\text { Determining the cost } \\
\text { of labor and the cost } \\
\text { of personnel }\end{array}$ \\
\hline Result & $\begin{array}{l}\text { Reward (individual } \\
\text { or collective) }\end{array}$ & $\begin{array}{l}\text { Stating the fact of } \\
\text { evaluation, confir- } \\
\text { ming job relevance } \\
\text { and level of profes- } \\
\text { sional competence, } \\
\text { taking an appropriate } \\
\text { personnel decision } \\
\text { etc. }\end{array}$ \\
\hline $\begin{array}{l}\text { Dominant } \\
\text { indicators }\end{array}$ & $\begin{array}{l}\text { Quantitative, } \\
\text { qualitative }\end{array}$ & Quantitative \\
\hline $\begin{array}{l}\text { - Essential } \\
\text { manifestation }\end{array}$ & $\begin{array}{l}\text { - Time and space } \\
\text { forms } \\
\text { - Objective and } \\
\text { subjective states } \\
\text { - Economic and } \\
\text { psychological } \\
\text { nature }\end{array}$ & $\begin{array}{l}\text { - Time and space } \\
\text { forms } \\
\text { - Real and potential } \\
\text { states } \\
\text { - Individual cont- } \\
\text { ribution to perfor- } \\
\text { mance } \\
\text { - Necessary } \\
\text { employees traits }\end{array}$ \\
\hline
\end{tabular}

Source: developed by authors

New challenges put new tasks on the agenda of motivational policies and personnel evaluation systems, they require integrated efforts in search of innovative methods and technologies, review of personnel and work evaluation criteria. Table 2 shows the major challenges of our century and new personnel evaluation tasks.
Table 2

New tasks of personnel evaluation in modern challenging conditions

\begin{tabular}{|l|l|}
\hline \multicolumn{1}{|c|}{ New challenges } & \multicolumn{1}{|c|}{$\begin{array}{c}\text { New tasks of personnel } \\
\text { evaluation systems }\end{array}$} \\
\hline $\begin{array}{l}\text { Democratization of social } \\
\text { processes, which gives } \\
\text { freedom of choice }\end{array}$ & $\begin{array}{l}\text { Comparative evaluation of } \\
\text { success and failure during a } \\
\text { certain career stage }\end{array}$ \\
\hline Intellectualization of society & $\begin{array}{l}\text { Review of competencies and } \\
\text { criteria for evaluating labor } \\
\text { effectiveness }\end{array}$ \\
\hline $\begin{array}{l}\text { Informatization and } \\
\text { virtualization of ecomony }\end{array}$ & $\begin{array}{l}\text { Reorientation of evaluation } \\
\text { policies and evaluation } \\
\text { procedure }\end{array}$ \\
\hline $\begin{array}{l}\text { Socialization and } \\
\text { humanization of labor }\end{array}$ & $\begin{array}{l}\text { Strengthening the social } \\
\text { dimension in the scale of } \\
\text { personnel and performance } \\
\text { evaluation }\end{array}$ \\
\hline $\begin{array}{l}\text { Introduction of cultural } \\
\text { component in the } \\
\text { management system }\end{array}$ & $\begin{array}{l}\text { Relations between evaluation } \\
\text { system and the type of } \\
\text { organizational culture }\end{array}$ \\
\hline $\begin{array}{l}\text { Reconsideration of the } \\
\text { category of quality as the } \\
\text { universal value of evolu- } \\
\text { tional development }\end{array}$ & $\begin{array}{l}\text { Evaluation of the develop- } \\
\text { ment potential of a multidi- } \\
\text { mensional person and his/her } \\
\text { career progression }\end{array}$ \\
\hline
\end{tabular}

Source: developed by authors

The growing tendencies specified in Table 2 in all spheres of society will definitely bring changes into the content of evaluation, will cause the review of the evaluation structure with different accents on the evaluation of personal qualities, quality of work and performance. The time factor today demonstrates the dynamic acceleration of all processes, dissemination of information, emergence of new professions, reduced product life cycles, request for new professional skills and competences, which also require simplification of evaluation procedures. Informatization of society will promote the use of information technologies (time management, for example, to study the intensity of labor) during the period of personnel evaluation. Social and humanistic tendencies facilitate the movement of evaluation technologies towards increasing the value of labor social efficiency. This applies not only to those companies that are already recognized as socially active but also to those that understand that social responsibility is a sign of the strong civil society. Quality, as an essentially different level of development, focuses on the quality values and parameter, this, in turn, changes the approach to motivating and evaluating personnel. All these challenges initiate changes in approaches to 
motivation of personnel and tasks of motivational policies as they reinforce such core categories as "complexity", "tension", "intensity", "importance" of work, which are the components of motivation.

Both motivation and evaluation of personnel is based on the principles of objectivity, accuracy, comprehensiveness, accessibility, timeliness, flexibility, which remain relevant today.

\section{research \\ Conclusions and perspectives of further}

In today's challenging conditions an innovative mechanism for managing the efficiency of personnel performance and labor should be formed. It has to integrally combine evaluation and motivation contexts and harmonize relations between employers, managers and workers. Personnel motivation and personnel evaluation are autonomous areas of working with people, but they have many common components, so with the appropriate and holistic approach to the selection of innovative mechanisms for their implementation it is possible to get the effect of synergy in using human potential and achieving success in the market. New challenges dictate new approaches but do not deny the use of those traditional methods of personnel motivation or evaluation that still preserve their relevance and effectiveness even in the face of change. Consequently, the task of HR-managers is to be able to combine innovation with tradition in the correct proportions.

Research into this direction of personnel management should continue but it should account innovative trends in economic development, management, society as a whole. Further research should be directed towards building a model of system-based assessment of latest impact factors influencing the formation of innovative motivational and evaluation policies at enterprises. Another research direction might be reviewing professional standards, and expanding the field of motivation and personnel evaluation criteria.

\section{References}

1. Vievska M. Motivation of Professional Self-realization in Order of the of Forming Managerial Competencies Strategy // M. Vievska, L. KrasoVska // High School. 2010. - No. 3-4. - P. 89-103.
2. Zaharchyn G. Formation and Evaluation of Managerial Staff of Enterprises And Organizations Motivation: monograph // G. Zaharchyn, N. Lyubomudrova. - Lviv, Lviv Polytechnic National University Publishing House, 2015. - 188 p.

3. Yeskov O. Staff Evaluation as an Important Factor for the Personnel Certification // O. Yeskov, M. Pashuta // Formation of Market Relations in Ukraine, 2007. - No. 3 (70). - 157 p.

4. Kolot A. Motivation, Promotion and Staff Assessment / A. Kolot. - K.: KNEU, 2003. - 224 p.

5. Labenska T. Development of Methods for Personnel Evaluation // T. Labenska // The State And The Regions. Series: Economics and Business, 2007. No. 4. - 160 p.

6. Libanova E. Values and Social Reality of Ukrainian Society / E. Libanova // Economics of Ukraine. - K., 2008. - No. 10 (563). - P. 120-136.

7. Lipych L. The Genesis of Labour Motivation Theories / L. Lipych, L. Pustyulha // Science and Economics. - 2010. - No. 1. - P. 114-117.

8. Prytula O. Motivational Mechanisms and Their Using in Business / O. Prytula. - Lviv. - Lviv: IRD NAS of Ukraine, 2003. - 216 p.

9. Sivashenko T. Modern Approaches to Staff Assessment / T. Sivashenko // Economic Analysis, 2011. - Issue 8, Part 2 - P. 315-317.

10. Sytnik O. Personnel Assessment in the System of Motivation / A. Sytnik, O. Kovalchuk // Actual Problems of Economy. - 2007. - No. 11. - P. 84-87.

11. Turchina V. The Main Directions of Work Efficiency Improving in Crisis Period / V. Turchina // Formation of Market Economy: zb. nauk. pr. - K.: KNEU, 2010. - Vol. 2. - P.427-436.

12. Harchishina O. Personnel Motivation Based on the Theory of Organizational Culture (Electronic Resource) / O. Harchishina // Economy. Management. Innovations. - 2014. - No. 1.

13. Chernenko $V$. Innovative Work and Motivational Bases Of Its Development / V. Chernenko // Ukraine: Aspects of Labor. - 2007. - No. 6. - P. 30-34.

14. Tsurcan S. Labour Productivity as a Part of Integrated Assessment Indicator of the Efficiency of Industrial Enterprise's Staff: Problems of Definition and Using / S. Tsurcan // Visnyk of Khmelnytsky National University. - 2011. - No. 4, Vol. 2. P. 216-219.

15. Shumakova I. Human Resources Potencial and its Impact on the Organizations Efficiency / I. Shumakova // Visnyk NTU "KPI". - 2010. - No. 22. P. 12-20. 